\title{
KRYSTIAN PILCH
}

\section{Wyrażenia przysłówkowe określające relacje przestrzenne w gwarze spiskiej (na podstawie danych z Korpusu Spiskiego)}

\section{Wstęp}

Określanie relacji przestrzennych jest jedną z domen przysłówków i wyrażeń przysłówkowych. W przypadku zarówno jednych, jak i drugich można znaleźć różnice znaczeniowe, gdy porównamy polszczyznę ogólną i gwarę; te same jednostki leksykalne mogą opisywać dwie różne relacje. Przykładem może być znany regionalizm na pole, który w południowych regionach Polski oznacza nie tylko dosłownie 'na rolę, na pole uprawne', ale także 'na zewnątrz budynku, na świeże powietrze'.

Na takich właśnie połączeniach wyrazów skupimy się w niniejszym tekście, ograniczając się do jednej z grup semantycznych, określających relacje przestrzenne w gwarze spiskiej. W kolejnych częściach artykułu przedstawię wyodrębnione przy pomocy Korpusu Spiskiego wyrażenia przysłówkowe, a następnie pokrótce opiszę ich znaczenie. Następnie dokonam podziału ciągów na grupy określające statyczność i kierunkowość ruchu, podając przykłady ze wspomnianej bazy danych.

Temat ten w gwarze spiskiej nadal pozostaje niezbadany, dlatego istnieje w dialektologii potrzeba opracowania go i dalszego rozwijania. Praca jest więc zaledwie początkiem szerszych badań na temat ciągów występujących w gwarze w funkcji przysłówkowej.

Jak wspomniałem, jako źródło danych wybrałem Korpus Spiski, ze względu na jego bardzo dobrą znajomość i na możliwości badań nad jednostkami wielowyrazowymi, jakie projekt ten umożliwia językoznawcom.

\section{Spisz i gwara spiska}

Spisz jest krainą geograficzną na południu Małopolski, rozciągającą się na terenie Polski i Słowacji. Do samej Polski należy ok. $195 \mathrm{~km}^{2}$. Region ten jest położony pomiędzy 
rzekami Białką a Dunajcem, od wschodu graniczy z Pieninami, a od północy z Niżnym Podhalem i Gorcami. Na zachodzie region sąsiaduje ze Skalnym Podhalem (Urząd Gminy Łapsze Niżne 2010).

Do polskiej części należy 15 miejscowości: Falsztyn, Frydman, Kacwin, Łapszanka, Łapsze Niżne, Łapsze Wyżne, Niedzica, Niedzica-Zamek, Trybsz, Dursztyn, Krempachy, Nowa Biała, Czarna Góra, Jurgów i Rzepiska.

Przesunięcia granic Spisza w przeszłości oraz wpływy różnorodnych języków: węgierskiego, słowackiego, rusińskiego czy niemieckiego (Sobierajski 1966-1978) były powodem powstania kodu, który jest od dawna uznawany za jedną z gwar polskich (Czambel 1906). Mowa mieszkańców tych 15 wsi była już opisana w pracach na temat jej fonologii (Sowa 1990), dyferencyjności w stosunku do innych systemów (Małecki 1928), a także z punktu widzenia socjolingwistyki (Grochola-Szczepanek 2012).

\section{Badania i problem wyrażeń przysłówkowych}

Wyrażenia przysłówkowe najczęściej są opisywane w badaniach dotyczących dwóch tematów. W pierwszym przypadku są to prace lub gramatyki stawiające je obok przysłówków. Wśród nich wyróżnić można zwłaszcza prace Renaty Grzegorczykowej (1999, 2007), a szczególnie pozycję Funkcje semantyczne i składniowe polskich przysłówków (1975). W drugim przypadku mamy do czynienia z badaniami na temat fraz przyimkowych, które ulegają adwerbializacji. Tutaj znowu można wymienić m.in. prace Krystyny Kleszczowej (2012) czy Alicji Nagórko (2001), a także przytoczoną powyżej pozycję R. Grzegorczykowej (1975).

W obu przypadkach autorki mają z oczywistych względów rację. Wyrażenia przysłówkowe pełnią w wypowiedzi najczęściej tę samą funkcję co przysłówki, a więc są określnikami czasownika, przymiotnika lub innego przysłówka (Grzegorczykowa 1999). Są to też najczęściej frazy przyimkowe, w tym derywaty odprzymiotnikowe prefiksalno-sufiksalne, np. po polsku. Najczęściej, choć nie zawsze, ponieważ ciągi takie jak tego dnia czy byle jak także spełniają w zdaniu podobną rolę.

Prace na temat wyrażeń przysłówkowych w gwarach także stawiają je na równi z przysłówkami, najczęściej derywowanymi od fraz przyimkowych. Już Stanisław Urbańczyk (1972) wspomina o „zwrotach przyimkowych” typu po lezoncku czy po stojoncku. W słownikach gwar frazy przyimkowe oznacza się kwalifikatorem przyst. (np. w SGO) lub w użyciu przyst. (np. SGLS), adekwatnie do opisów podobnych jednostek w polszczyźnie ogólnej. Przykładem ujęć leksykograficznych jest WSJP PAN, w którym mamy do czynienia z ,frazami przysłówkowymi”, np. na oślep, na papierze czy nie na miejscu, które istnieją obok ,,przysłówków”, tj. na poważnie czy na serio. Przysłówki i ciągi odgrywające ich rolę w zdaniu są więc w wielu przypadkach uznawane za niemal jednakowe pod względem pełnionej funkcji. Problem sięga jednak głębiej.

To, czym jest przysłówek, jest nadal sprawą dyskusyjną w lingwistyce. Ujęcie tej części mowy w rozumieniu R. Grzegorczykowej (1999) także jest odmienne od podejścia innych badaczy. Na przykład Maciej Grochowski podejmował próby rozróżnienia 
przysłówków od partykuł (1986), a później Jadwiga Wajszczuk (2005) odróżniła od przysłówków tzw. operatory metapredykatywne typu bardzo, całkiem, nadzwyczaj. Czasami zamiast rozbudowywania wewnętrznych podziałów badacze proponują uogólnienia, jak w literaturze zachodniej, gdzie mówi się o adwerbialiach (adverbials) (Austin i in. 2004). Problem odróżnienia przysłówków od innych części mowy stał się tematem dyskusji i porównań zarówno w polszczyźnie, jak i za granicą ${ }^{1}$. Powstaje pytanie: czy rozróżnianie wyrażeń przysłówkowych i przysłówków ma sens, skoro sama klasa przysłówków nie jest jednoznacznie określona?

Z perspektywy rozwoju nowych metod językoznawczych, takich jak lingwistyka korpusowa - zdecydowanie tak. Problemy z ekstrakcją jednostek wielowyrazowych w bazach tekstowych są nadal obecne ${ }^{2}$. Ponadto mowa tu tylko o bazach danych języka ogólnego. Systemy gwarowe potrzebują tworzenia odrębnej metodologii wydobywania ciągów leksykalnych. Wynika to z wielu przyczyn, m.in. z leksykalizacji niektórych ciągów, które w systemie ogólnym nie są lub są rzadko uznawane za odrębne jednostki (patrz: przykład na pole) czy struktur, które w polszczyźnie ogólnej mogłyby zostać za błędne (np. być od Zakopanego w gwarowym znaczeniu 'pochodzić z Zakopanego' lub jeździć z koniem w gwarowym znaczeniu ‘jeździć konno’). Jednym z projektów podejmujących to wyzwanie jest Korpus Spiski.

\section{Dyferencyjne wyrażenia przysłówkowe}

Ze względu na rozbieżności w próbach definiowania przysłówka czy szerzej adwerbialiów ${ }^{3}$ podjąłem decyzję, aby w artykule do samych wyrażeń przysłówkowych odnieść się w sposób podobny do metodologii przyjętej podczas pracy nad powstawaniem Korpusu Spiskiego. W ten sposób została wypracowana poniższa definicja, która była skuteczna w wyodrębnianiu poszukiwanych jednostek:

Dyferencyjne wyrażenie przysłówkowe jest to ciąg co najmniej dwóch wyrazów, które razem funkcjonują w tekście jako odrębna jednostka dyferencyjna, funkcjonująca w zdaniu jako określnik czasownika, przymiotnika lub przysłówka.

Ta krótka definicja zawiera w sobie najważniejsze elementy potrzebne do odróżnienia dyferencyjnych wyrażeń przysłówkowych od innych ciągów.

Po pierwsze, dane wyrażenie musi cechować się dyferencyjnością, co jest rozumiane tutaj jako odrębność w stosunku do polszczyzny ogólnej. W niektórych przypadkach będą to ciągi mające tę samą formę w kodzie ogólnym i gwarowym, ale różne znaczenie, np. do góry oznaczające w gwarze 'w kierunku wyżej położonej części miejscowości'.

\footnotetext{
1 Wspomina o tym Emilia Kubicka w swoich artykułach (2010, 2013).

${ }^{2}$ Bardzo obszernie na temat problemów z ekstrakcją wielowyrazowych jednostek języka można przeczytać w pracy Michała Woźniaka Jak znaleźć igłę w stogu siana? (2017).

3 Jeśli odnieść się do przytoczonej literatury zagranicznej.
} 
W innych przypadkach mogą to być formy zawierające elementy nieznane w ogólnej odmianie języka, np. na lezóncku oznaczające 'w pozycji leżącej, na leżąco'.

Po drugie, jak już zaznaczono, nietrudno stwierdzić, że tak opisaną funkcję w zdaniu będą najczęściej pełniły ciągi zaczynające się od przyimka (Grzegorczykowa 1999) i z tego też powodu na zbiorze takich form będzie koncentrował się artykuł. W Korpusie Spiskim odnotowano ponad 300 przykładów wyrażeń z pierwszym członem przyimkowym. Z powodu dużej ich liczby do analizy wybrano mniejszy zbiór wyrażeń, których znaczenie określa wyłącznie relacje przestrzenne, tj. 72 ciągi.

Co najważniejsze, podana definicja jest najbliższa tej przyjętej podczas tworzenia Korpusu Spiskiego. W podobny sposób w trakcie trwania projektu odróżniano dyferencyjne jednostki języka o funkcji przysłówkowej od zwykłych fraz przyimkowych pełniących często podobną funkcję, lecz nie mających odrębnego od polszczyzny znaczenia. Dla przykładu „dwieście metrów za drogą” dla użytkownika ogólnej odmiany języka polskiego może znaczyć 'dwieście metrów stąd po przekroczeniu jakiejś jezdni', a dla użytkownika gwary spiskiej może także (szczególnie w przypadku odnoszenia się do głównej drogi przecinającej miejscowość) oznaczać 'dwieście metrów stąd, idąc wzdłuż drogi'.

\section{Korpus Spiski}

Nowe technologie informatyczne stosowane obecnie w językoznawstwie pozwalają na tworzenie ogromnych baz danych. Jednym $\mathrm{z}$ takich projektów, pionierskim w dziedzinie dialektologii polskiej, jest Korpus Spiski (2015-2019). Jako cel główny obrano dokumentację ,języka mieszkańców Spisza oraz opracowanie elektronicznej bazy tekstów i nagrań gwarowych z tego terenu" (Grochola-Szczepanek i in. 2019).

Korpus zawiera ponad 250 godzin nagrań gwarowych z mieszkańcami wszystkich 15 miejscowości Spisza. Innowacją jest możliwość odsłuchiwania wypowiedzi z jednoczesnym dostępem do transkrypcji i metadanych na temat płci mówiącego, miejscowości pochodzenia, wykształcenia czy roku urodzenia. Ponadto baza nie jest zbiorem nagrań wyłącznie najstarszych mieszkańców Spisza; najmłodsi informatorzy urodzili się w pierwszym dziesięcioleciu XXI w. Powszechny dostęp przez internet pozwala na korzystanie z zasobów korpusu zarówno badaczom języka, jak i miłośnikom gwary (Grochola-Szczepanek i in. tamże).

Jednostki wielowyrazowe były oddzielnie oznaczane podczas tworzenia korpusu. Najprostszym sposobem ich znalezienia jest wpisanie kwerendy w wyszukiwarce. Innym sposobem jest skorzystanie ze słownika, w którym wynotowano wszystkie jednostki dyferencyjne, także te wielowyrazowe. Dla przykładu poniższy schemat pokazuje ciąg do góry, wyszukany przy pomocy pierwszej metody. Podkreślone wyniki są wyróżnione jako jednostki dyferencyjne, a więc są odróżniane od wyrażeń mających znaczenie ogólnopolskie (bez podkreślenia). Decyzje o tym, które jednostki wielowyrazowe należało wyróżnić ze względu na ich odmienną semantykę, zostały podjęte przez badaczy w trakcie opracowywania bazy danych podczas licznych dyskusji. 


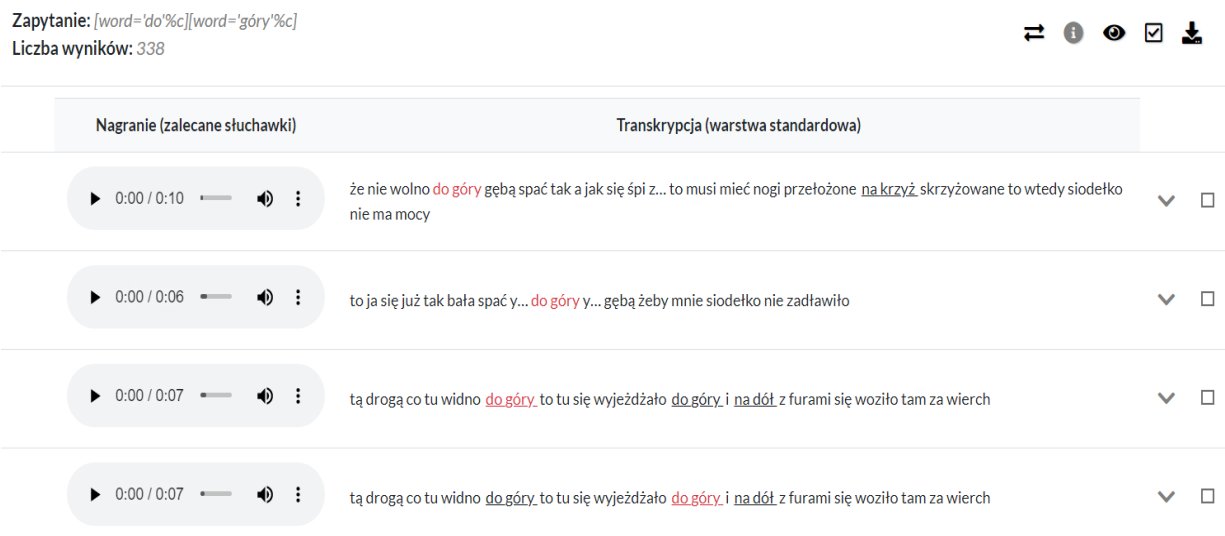

\section{Zbiór wyrażeń określających relacje przestrzenne i ich znaczenie}

Poniższa tabela prezentuje omawiane wyrażenia przysłówkowe. Dla przejrzystości i ułatwienia dalszej analizy podzielono ją ze względu na typ przyimka. Użyto zapisu półfonetycznego, który odzwierciedla oryginalną wymowę stosowaną przez respondentów.

\begin{tabular}{|l|l|}
\hline \multicolumn{1}{|c|}{ przyimek } & \multicolumn{1}{c|}{ wyrażenie } \\
\hline do & do góry, do lewa, do nuka, do pola, do prawa, do przodku, do zadku \\
\hline na & $\begin{array}{l}\text { na dole, na dól, na górach, na góre, na górze, na izbaf / na izbak, na } \\
\text { izbece, na izbie, na lezóncku, na ogrodzie, na pole, na polu, na poprzyk, na } \\
\text { posprzyc, na pozdłuź, na prosto, na przodek, na przodku, na spodek, na } \\
\text { spodku, na stajni, na sopaf / na sopak, na sope, na sopie, na śród, na wiyr- } \\
\text { chu, na zdłuź, na zadek, na zadku }\end{array}$ \\
\hline od & od dołu, od góry, od przodku, od spodku, od zadku \\
\hline po & po dole, po polu, po prawej rynce \\
\hline pod & pod dach, pod spodek, pod wiyrch, pod pazuche \\
\hline u & u wiyrchu \\
\hline w / we & w dachu, $w$ górze, $w$ góre, $w$ pole, $w$ zod, $w$ zadku, we wiyrchu \\
\hline z / ze & $\begin{array}{l}\text { z bylekónd, z choćkónd, z dalsa, z dołu, z góry, z kraja, z pola, z przodku, } \\
\text { ze spodku, ze zadku }\end{array}$ \\
\hline za & za drogóm, za pazuche, za pazuchóm, za wodóm, za wode \\
\hline zza & $z z o$ wody \\
\hline
\end{tabular}


Można zauważyć, że większą część wyrażeń przysłówkowych określających relacje przestrzenne w gwarze spiskiej stanowią formy, które można spotkać w kodzie ogólnym, jak np. do góry, do pola, na dole, na dót, na krziz, pod dach, za wode itd. W realiach wiejskich te niepozornie pospolite ciągi zyskują jednak inne znaczenie.

Określenie na pole jest znane jako regionalizm oznaczający 'na zewnątrz'. W gwarze spiskiej posiada on różne, lecz semantycznie blisko powiązane realizacje: do pola, na pole, na polu, w pole, z pola. Wyjątkiem jest tutaj wyrażenie do pola, którego drugie znaczenie jest następujące: 'o ubraniu: w sposób, w którym wewnętrzna część ubrania znajduje się na zewnątrz; na lewą stronę’.

Ciągi posiadające różną realizację form góra i dół wskazują na powszechne w gwarze spiskiej określanie części miejscowości ściśle powiązane z zabudową na zróżnicowanym poziomie wysokości. Góra to zawsze domostwa położone wyżej, idąc wzdłuż głównej drogi, a do dołu należą zabudowania położone niżej. Stąd też pojawia się często podział mieszkańców na górzón / górzanów i dolón / dolanów, rzadziej też środkowianów. Wyjątkiem jest tutaj ciąg na górach, w którym zastosowanie liczby mnogiej określa Podhale. Do grupy tych wyrazów można też dołączyć ciąg za drogóm, który określa kierunek ruchu wzdłuż głównej drogi danej miejscowości.

Wyrażenia z różnymi realizacjami form izba, izbecka, dach, sopa, stajnia i ogród także określają inne miejsca niż w polszczyźnie ogólnej. Pierwsze trzy mówią o strychu (na izbaf / na izbak, na izbece, na izbie), kolejne dwa o stodole (na stajni, na sopaf / na sopak, na sope, na sopie), zaś ostatnie o podwórku (na ogrodzie). Jest to także powiązane z budową domostw, gdzie np. pod dachem wędzono mięso. Podobnie siano było przechowywane na piętrze położonym bezpośrednio nad stajnią, a więc na stajni.

Wiyrch w gwarze zastępuje podobnie brzmiące słowo wierzch. Tutaj trzeba też zwrócić uwagę na ciągi pod wiyrch, który oznacza 'na wierzch' i we wiyrchu w drugim znaczeniu 'na zewnątrz'. Antonimiczne znaczenie, tzn. spód czegoś, określają ciągi z różnymi formami jednostki spodek, która w kodzie ogólnym nazywa rodzaj talerza.

Ciągi z różnymi formami hasła przodek służą określaniu położenia lub kierunku przedniego. Wyrażenia z formami haseł zad i zadek, odwrotnie, opisują położenie i kierunek z tyłu. Człony takich wyrażeń charakteryzują się także tym, że mogą funkcjonować jako samodzielne wyrazy - przodek i zadek, oznaczające kolejno 'przód' i 'tył'. Najczęściej jednak spotyka się je w połączeniach.

Rzeka Białka stanowi jedną z naturalnych granic Spisza i Podhala. Stąd też określenia z formą woda oznaczają 'po drugiej stronie rzeki Białki, czyli na Podhalu'. Wyjątkiem jest ciąg za wode, którego definicja to 'kierunek podróży / emigracji do Stanów Zjednoczonych'.

Wyrażenia do lewa, do prawa, po prawej rynce, na poprzyc, na poprzyk, na pozdluź, na zdtuź, na śród i z kraja posiadają formy charakterystyczne dla gwary, ale mogą słusznie przywodzić na myśl ogólnopolskie odpowiedniki: 'w lewo', 'w prawo', 'w poprzek', 'na wzdłuż', 'na środek / do środka' i 'z krawędzi / z brzegu'. Formy wyrażeń do lewa 
i do prawa ${ }^{4}$ można spotkać w języku słowackim. Ciąg po prawej rynce jest w kodzie ogólnym realizowany poprzez formę 'po prawej stronie'.

Pozostałe wyrażenia są dyferencyjne stricte ze względu na obce kodowi ogólnemu formy ich członów. Ciąg na lezóncku jest synonimiczny z formą 'na leżąco'. Nie jest znana forma samodzielna drugiego członu. Wyrażenia $z$ bylekónd i $z$ choćkónd są tożsame znaczeniowo, a ich definicja brzmi 'z różnych miejsc'. Pazucha w ciągach pod pazuche, za pazuche i za pazuchóm oznacza 'wgłębienie między wewnętrzną stroną ramienia a bokiem klatki piersiowej’, czyli najprościej mówiąc 'pachę’.

\section{Relacje lokatywne, adlatywne, ablatywne i perlatywne}

W tej części zostaną opisane rodzaje relacji przestrzennych, jakimi cechują się zebrane wyrażenia, ze zwróceniem uwagi na przypadek, z którym łączą się przyimki. Klasyfikacja została zaczerpnięta od Adama Weinsberga (1973). Odnosi się ona formalnie do przyimka i formy przypadka kolejnego członu ciągu, a semantycznie do relacji przestrzennej, co uznaję za najbardziej praktyczne rozwiązanie w tym artykule 5 .

Wyróżnione relacje to:

- relacje lokatywne (gdzie znajduje się X?),

- adlatywne (do jakiego celu lub w jakim kierunku podąża X?),

- ablatywne (z jakiego miejsca lub skąd porusza się X?)

- perlatywne (którędy podąża X?).

Pierwszą relację określa się też jako statyczną, a pozostałe trzy ogółem jako kierunkowe lub latywne.

Relacje lokatywne są wyrażone przez połączenia:

- $u, z / z e+$ D. (u wiyrchu, z przodku, ze spodku, ze zadku),

- $z a+$ N. (za wodóm, za pazuchóm),

- $\quad n a, p o, w / w e+$ Mc. (na dole, na górach, na górze, na izbaf/na izbak, na izbece, na izbie, na izbie, na lezóncku, na ogrodzie, na polu, na przodku, na spodku, na stajni, na sopaf / na sopak, na sopie, na wiyrchu, na zadku, po prawej rynce, w zadku, $w$ dachu, w górze, we wiyrchu).

Relacje ablatywne wyrażają połączenia wyłącznie z dopełniaczem:

- od, z, zza + D. (od dotu, od góry, od przodku, od spodku, od zadku, z bylekónd, z choćkónd, $z$ dalsa, $z$ dotu, z góry, z kraja, z pola, zzo wody).

Relacje adlatywne są widoczne w połączeniach:

- do + D. (do góry, do lewa, do nuka, do pola, do prawa, do przodku, do zadku),

\footnotetext{
${ }^{4}$ Wyrażenie do prawa jest też znane w gwarze orawskiej w określeniu chodzić do prawa jako 'dochodzić swoich praw w sądach, procesować się’ (Kąś 2010), jednak nie stwierdzono takiego zastosowania w Korpusie Spiskim.

${ }^{5}$ W podobny sposób do tego typu relacji odnoszą się w swoich pracach Okoniowa (1987) i Greń (1992).
} 
- na, pod, w, za + B. (na dót, na góre, na pole, na przodek, na spodek, na sope, na śród, na zadek, pod dach, pod pazuche, pod spodek, pod wiyrch, w pole, w góre, w zod, za pazuchę, za wode).

Relacje perlatywne są spotykane wśród połączeń:

- $\quad n a, z a+$ B. (na poprzyk, na posprzyc, na pozdluź, na prosto, na zdluź, za pazuche, $z a$ wode),

- $z a+$ N. (za drogóm, za pazuchóm),

- po + Mc. (po dole, po polu).

W powyższym podziale można zwrócić uwagę na relacje wspólne, wyrażane przez te same połączenia przyimka i przypadka. Biernik łączy się z przyimkiem $n a$ dla określenia tego, w jakim kierunku i którędy przebiega ruch (por. perlatywne na prosto 'na wprost' i adlatywne na przodek 'do przodu, w kierunku przedniej części czegoś'). W przypadku przyimka $z$ i dopełniacza tylko $z$ przodku wykazuje w niemal stu procentach znaczenie lokatywne, podczas gdy pozostałe ciągi wyrażają adlatywność. Tylko jeden przykład z przodku wśród 46 poświadczeń jest użyty w relacji kierunkowej:

1948-Niedzica-K ${ }^{6}$

Z przodku lecym, na ganku durkóm na to okno.

Podobnie rzecz ma się z połączeniem po i miejscownika. Tylko po prawej rynce ma odniesienie statyczne; pozostałe ciągi określają relację perlatywną. Ostatni przypadek to para połączeń za i narzędnika: za drógóm odnosi się do perlatywności, podczas gdy za wodóm do lokatywności.

1941-Dursztyn-M

Tutok jak idziecie za drógóm, tu w kierunku Krempach. (w znaczeniu 'wdłuż drogi' dop. K.P.)

\section{4-Czarna Góra-M}

No to nawet byłek tam za wodóm w Białce.

Patrząc z innej perspektywy, można częściej wymienić połączenia przyimka i przypadka charakterystyczne tylko dla jednej grupy relacji:

- tylko lokatywne: $u+\mathrm{D} ., z e+\mathrm{D} ., n a, w / w e+$ Mc.,

- tylko ablatywne $-o d+\mathrm{D}$., $z z a+\mathrm{D}$.,

- tylko adlatywne $-d o+$ D., pod + B., $w+$ B., $z a+$ B.,

- tylko perlatywne - brak.

${ }^{6}$ Kod wypowiedzi informatora to kolejno rok urodzenia, miejscowość pochodzenia i płeć (K - kobieta, M - mężczyzna). 
Ponadto należy zwrócić uwagę na fakt, że biernik występuje tylko w ciągach o relacji adlatywnej.

Można zauważyć, że wyrażenia przestrzenne są używane na ogół w sposób podobny do standardowej odmiany polszczyzny. Relacje statyczne (lokatywne) wyrażane są głównie za pomocą przyimków w, we (z miejscownikiem), u, ze, zza (z dopełniaczem) i za (z narzędnikiem), choć pojawiają się wyjątki: w pole, w zod, za pazuche, za wode, które wyraźnie wskazują na kierunek:

1980-Jurgów-K

Trza było dziesi iść w pole.

1942-Łapszanka-M

Trzy razy się pokrop w zad.

\section{2-Kacwin-K}

No to wziyni kołacz pod pazuche, wódkę i k... od domu śpiewali, szli namo... namawiać.

\section{8-Trybsz-K}

Suchego chleba wziynaf, za pazuche wraziła i popiła wodą.

\section{3-Nowa Biała-M}

Miał jedenaście kóz, to w zimie wyganiał do Kramnice za wode.

Rzeczowniki łączą się w takiej sytuacji nie z miejscownikiem, jak w przypadku relacji lokatywnych (np. w górze), ale z biernikiem. Użycie przyimków $w$ i we jest więc w gwarze rozszerzone pod tym względem. Użycie $z a \mathrm{w}$ relacji kierunkowej nie jest obce polszczyźnie ogólnej.

Ponadto można wyróżnić pary ciągów lokatywnych, które mają swój latywny odpowiednik:

- na dole / na dół,

- na górze / na góre,

- na polu / na pole,

- na przodku / na przodek,

- na sopie / na sope,

- na zadku / na zadek,

- w górze / w góre,

- za wodóm / za wode.

Najwięcej takich par można znaleźć wśród ciągów z przyimkiem na ze względu na ich największą liczbę poświadczeń. 


\section{Podsumowanie}

Analiza wyodrębnionych wyrażeń przysłówkowych pozwala na wyciągnięcie następujących wniosków:

- Większość ciągów jest graficznie bliska formom ogólnopolskim (tylko fonetyka gwary wpływa na formę), ale znaczeniowo różna. Np. ciąg na sopie można uznać za dyferencyjną jednostkę leksykalną, ponieważ w polszczyźnie ogólnej nazywa on dosłownie miejsce nad szopą (na dachu szopy), podczas gdy w gwarze spiskiej nazywa konkretne przykryte dachem dodatkowe piętro, znajdujące się zazwyczaj nad stajnią.

- Nieliczne ciągi mają formy nieznane polszczyźnie ogólnej. Są to: do lewa, do prawa, po prawej rynce, na poprzyc, na poprzyk, na pozdtuź, na zdtuź, na śród, z kraja, na lezóncku, z bylekónd, z choćkónd, pod pazuche, za pazuche i za pazuchóm.

- Pomimo różnic znaczeniowych relacje przestrzenne cechują się w gwarze podobną strukturą jak w polszczyźnie ogólnej, tzn. przyimki łączą się z podobnymi formami przypadka.

- Ciągi określające relacje przestrzenne to ok. 20\% wszystkich wyrażeń przysłówkowych. Gwara spiska jest więc bogata w zróżnicowane określenia dotyczące kierunku ruchu i statyczności.

Jak wspomniałem na samym początku, artykuł ten jest zaczątkiem szerszych badań nad wyrażeniami przysłówkowymi. Czy takie badania mają jednak sens? Odpowiedź jest zdecydowanie pozytywna. Gwara spiska bogata jest w jednostki wielowyrazowe, które pełnią funkcję przysłówkową. W artykule opisano jedynie część z nich, tj. przypadki określające relacje przestrzenne. Powyższa lista nie wyczerpuje pełnego zbioru takich ciągów. Planowane są dalsze prace opisujące relacje czasowe, sposobu, ilości i jakości. Jako dodatkowy wniosek można dodać zauważalny potencjał korpusów, które są ogromnym ułatwieniem w wyszukiwaniu takich jednostek, pod warunkiem że dany projekt bierze takie jednostki pod uwagę już w początkowej fazie opracowywania uzyskanego materiału.

\section{Bibliografia}

Austin J.R. i in., 2004., Current issues in the syntax and semantics of adverbials, [w:] J.R. Austin i in., Adverbials: the interplay between meaning, context, and syntactic structure, Amsterdam - Philadelphia. Czambel S., 1906, Slovenská reč a jej miesto v rodine slovanských jazykov. I. Osnovy a iný materiál rečový, 1. Východnoslovenské nárečie, Turč. Sv. Martin.

Greń Z., 1992, Przyimki kierunkowe i miejscowe w gwarach południowocieszyńskich, [w:] Studia z dialektologii polskiej i słowiańskiej, red. W. Boryś, W. Sędzik, Warszawa, s. 75-81.

Grochola-Szczepanek H., 2012, Język mieszkańców Spisza, Płeć jako czynnik różnicujący, Kraków.

Grochola-Szczepanek H. i in., 2019, Korpus języka mówionego mieszkańców Spisza, LingVaria 27, s. 165180.

Grochowski M., 1986. Polskie partykuły. Składnia, semantyka, leksykografia, Wrocław.

Grzegorczykowa R., 1979, Zarys słowotwórstwa polskiego. Słowotwórstwo opisowe, Warszawa.

Grzegorczykowa R., 1999, Słowotwórstwo przysłówków [w:] Gramatyka współczesnego języka polskiego. Morfologia, red. R. Grzegorczykowa, R. Laskowski, H. Wróbel Warszawa, s. 524-534. 
Grzegorczykowa R., 2007, Wstęp do językoznawstwa, Warszawa.

Kleszczowa K., 2012, Wyrażenia przyimkowe w polskiej derywacji, [w:] Творба речи и њени ресурси у словенским језицима, уредници Б. Ћорић и Р. Драгићевић, Београд, s. 121-129.

Kubicka E., 2010. Przysłówek na tle innych części mowy w językoznawstwie polskim i niemieckim, Język Polski XC, s. 107-115.

Kubicka E., 2013. Skąd się biorą przysłówki, czyli dlaczego łatwiej opisywać adwerbialia niż adwerbia, Poradnik Językowy, nr 9, s. 89-101.

Małecki M., 1928, Spiskie -ô, [w:] Symbolae grammaticae in honorem Ioannis Rozwadowski, t. 2, Kraków, s. 443-449.

Nagórko A., 2001, Przyimki a słowotwórstwo przysłówków, Prace Filologiczne XLVI, s. 453-462.

NKJP: Narodowy Korpus Języka Polskiego (online: nkjp.pl).

Okoniowa J., 1987, Polskie przyimki gwarowe. Znaczenia przestrzenne i czasowe, Wrocław.

SGO: Kąś, J., 2011, Słownik gwary orawskiej, wyd. 2, Kraków.

SGLS: Szewczyk Z.P., 2014, Słownik gwary Lachów Sądeckich, Podegrodzie.

Sobierajski Z., 1966-1978, Atlas polskich gwar spiskich na terenie Polski i Czechosłowacji, t. 1-4, Poznań.

Sowa F., 1990, System fonologiczny polskich gwar spiskich, Wrocław - Warszawa - Kraków.

Urbańczyk S., 1972, Zarys dialektologii polskiej, Warszawa.

Urząd Gminy Łapsze Niżne, 2010, Spisz - kraina wielu kultur, Tarnów.

Wajszczuk J., 2005, O metatekście, Warszawa.

Weinsberg A., 1973, Przyimki przestrzenne w języku polskim, niemieckim i rumuńskim, Wrocław.

Woźniak M., 2017, Jak znaleźć igłę w stogu siana? Automatyczna ekstrakcja wielosegmentowych jednostek leksykalnych z tekstu polskiego, Kraków.

WSJP PAN: Wielki słownik języka polskiego PAN, 2007-, red. P. Żmigrodzki (online: wsjp.pl).

\section{STRESZCZENIE}

Słowa kluczowe: przysłówki, jednostki wielowyrazowe, gwara spiska, korpus.

Artykuł jest przyczynkiem do badań nad wyrażeniami przysłówkowymi w gwarze spiskiej. Analizie poddane zostały ciągi określające relacje przestrzenne. W pierwszej części zaprezentowano zbiór zebranych haseł i objaśniono ich znaczenie. Następnie dokonano ich podziału ze względu na lokatywność i latywność, wskazując na przyimek i towarzyszący mu przypadek, warunkujący wyrażenie danej relacji. Analiza oparta jest na materiałach z Korpusu Spiskiego.

\section{SUMMARY}

\section{Adverbial phrases defining spatial relations in the Spisz dialect (based on data from the Spisz Dialect Corpus)}

Keywords: adverbs, phrases, Spisz dialect, corpus.

The article is supposed to be a foundation for future analyses of adverbial phrases in the Spisz dialect. The work focuses on expressions describing spatial relations. Firstly, a collection of such phrases is introduced along with their definitions. Secondly, the phrases are divided into groups defining stillness and movement, simultaneously pointing at their preposition and case used to describe a given relation. The data was provided by the Spisz Dialect Corpus. 